\title{
M. E. Sosa Torres, P. M. H. Kroneck (Volume Eds): Sustaining life on planet earth: metalloenzymes mastering dioxygen and other chewy gases. Volume 15 of Metal Ions in Life Sciences, Series Eds A. Sigel, H. Sigel, R. K. O. Sigel
}

\author{
Springer International Publishing AG, Switzerland, 2015, 329 pp [ISSN 1559-0836; \\ ISSN 1868-0402 (electronic); ISBN 978-3-319-12414-8; ISBN 978-3-319-12415-5 (eBook); \\ DOI 10.1007/978-3-319-12415-5]
}

\author{
Robert R. Crichton ${ }^{1}$ \\ Received: 20 January 2016/ Accepted: 20 January 2016/Published online: 3 February 2016 \\ (C) Springer International Publishing Switzerland 2016
}

This is an interesting and timely volume in the long-running series 'Metal Ions in Life Sciences' edited by Astrid and Helmut Sigel, now joined by their son Roland, which has changed publishers in the last decade with astonishing regularity. Since the original 44 volumes of 'Metal Ions in Biological Systems' had been published by Marcel Decker/ Taylor and Francis, the new series has passed successively via Wiley, the Royal Society of Chemistry, and Springer to De Gruyter, where MILS-5 through MILS-9 have found a new home, and where from 2017 on the MILS volumes will be published.

The major emphasis in volume 15 is on the only clearly designated gas of biological interest, oxygen, the mastering of which is represented by chapters on photosystem II, cytochrome c oxidase, and the haem enzymes involved in dioxygen activation, together with an authoritative review of the potential of iron and copper complexes in the same process (with the inconvenience of lacking critical analysis of Nature's extensive evolutionary experience guiding it to infinitely better outcomes). Interspersed in the middle of this is a chapter which, in my opinion, could have been omitted, devoted to the only enzyme capable of coupling two oxygen atoms, chlorite dismutase; however, its mode of action does not appear to point any flashing lights to pathways of dioxygen generation distinct from PSII. The final two chapters present authoritative reviews on the oxidation of methane by particulate and soluble methane monooxygenases and the nitrite-driven anaerobic oxidation of ammonium and methane by 'impossible' microorganisms.

I can warmly recommend this book to affectionados of metals in biology - an absolute must-but I warn native English-speaking readers to exercise a large dose of generosity in approaching the text-apart from my incapacity, after reading the volume, to clearly establish why ammonia and methane are 'chewy gases', there was an appalling lack of copy-editing which, for example, rendered parts of the final chapter almost incomprehensible.

Robert R. Crichton

robert.crichton@uclouvain.be

1 Universite Catholique de Louvain, Batiment Lavoisier, Place Louis Pasteur 1, 1348 Louvain-la-Neuve, Belgium 